\title{
RESENHA DE "ENSINO DE LÍNGUA MATERNA: PCNS, GRAMÁTICA E DISCURSO” [WITTKE, C. I. - SANTA CRUZ DO SUL: EDUNISC, 2007]
}

Tânia Winch Lisbôa* Onici Claro Flores*

A obra "Ensino de língua materna: PCNs, gramática e discurso", de Cleide Inês Wittke, publicada em 2007, pela Edunisc, é um importante suporte teórico tanto para professores de Português dos ensinos fundamental e médio, quanto para professores e acadêmicos de cursos de letras, que se preocupem com o ensino da língua materna (LM) no sentido de criar significado para o aluno.

Contando com 184 páginas, o volume traz, já na introdução, a preocupação da autora em relação às práticas tradicionais do ensino da LM, propondo um enfoque discursivo através do estudo das orações subordinadas introduzidas por pronomes relativos.

Para situar o leitor, Wittke, no primeiro capítulo, sintetiza e clareia o texto original dos PCNs, explicitando como este texto idealiza o ensino de LM na escola e aponta que uma teoria semântico-argumentativa, como a ANL/TBS (Teoria da Argumentação na Língua/Teoria dos Blocos Semânticos) pode tornar essa prática viável.

Faz um comentário favorável à implantação efetiva dos PCNs, entretanto questiona se, de modo geral, os professores estão realmente preparados para isso. Temendo esse despreparo por parte dos professores, Wittke enfatiza a importância de cursos de aperfeiçoamento, no sentido de entender essa nova forma de trabalhar a Língua

\footnotetext{
* Mestranda em Letras na Universidade de Santa Cruz do Sul (UNISC), Santa Cruz do Sul, RS, Brasil.Email: <taniawlisboa@yahoo.com.br>.

** Professora do Mestrado em Letras da UNISC, Santa Cruz do Sul, RS, Brasil. Doutora em Letras. Email: <oflores@unisc.br>.
} 
Portuguesa em sala, concebida como um ato interlocutivo, o que não significa dizer abolir o ensino da gramática.

No entender da pesquisadora faz-se necessária também uma nova postura dos Cursos de Letras, reformulando seus currículos e renovando seus pressupostos teóricos no que tange à concepção de língua e linguagem.

Para facilitar esses estudos, tanto para professores que já atuam em sala quanto para acadêmicos, indica como possibilidade de referência teórica a Semântica Argumentativa de Ducrot e Carel, além do dialogismo de Bakhtin, da abordagem enunciativa de Benveniste, entre outras teorias.

Para fechar o capítulo um, analisa como o estudo da ANL/TBS pode possibilitar a implementação dos PCNs nas aulas de LM, fundamentando essa hipótese no fato de a Semântica Argumentativa de Ducrot, assim como os PCNs, defenderem uma proposta de ensino da língua baseada no caráter interativo, enunciativo da linguagem, o que leva a uma articulação entre língua e fala, valorizando a perspectiva discursiva da língua e consequentemente da interação com o meio social do falante.

Para que aconteça a consolidação dos PCNs, é imprescindível que ocorra antes a reavaliação das práticas de ensino da gramática tradicional. No entanto, para o professor reavaliar, é necessário conhecer os diferentes tipos de gramática, e para tanto a autora apresenta no capítulo dois um estudo da gramática propriamente.

Abre o capítulo dois, citando estudiosos como Hauy, Geraldi, Possenti, Travaglia e Neves, no que diz respeito a estudos da língua como processo interativo. Ao citar esses autores, descortina um leque de possibilidades de leituras para o professor interessado em repensar suas práticas de ensino, bem como em ampliar o universo teórico sobre o assunto, embora a proposta do capítulo seja criar um panorama histórico do desenvolvimento da gramática, desde sua origem até o século XX, com as teorias estruturalistas e gerativistas fundadoras da Linguística, que, mesmo sendo originárias da tradição gramatical, buscam uma renovação metodológica.

$\mathrm{Na}$ sequência do texto, ela explica as gramáticas normativa, descritiva e interna, citando os teóricos de cada linha de conhecimento. 
Tendo em vista que o objeto de estudo da obra são as orações subordinadas relativas (ou adjetivas), a autora aborda esse fenômeno linguístico a partir de cada um dos tipos de gramática, iniciando pela perspectiva da gramática normativa, passando pela gramática descritiva e pela gramática de usos (funcional).

Considerando as três gramáticas tratadas, ela conclui que a oração relativa pode ser entendida como sintaticamente dependente da oração principal. Além disso, o fato de ser introduzida por um pronome relativo, exceto no caso das orações reduzidas, pode ser considerado importante, embora, para a autora, a importância das orações relativas resida no valor argumentativo delas, já que o enfoque proposto é semântico (enunciativo) e não morfo-sintático.

O capítulo três retoma a importância dada pelos PCNs ao estudo da língua voltado ao discurso, sob o enfoque enunciativo, resgatando o questionamento: como tornar a proposta dos PCNs viável? A autora encontra, como possível saída, fazer com que a ANL/TBS sirva de base teórica para o ensino de LM, em especial das orações relativas, mas acredita que, para uma mudança significativa didático-pedagógica, tornase indispensável o domínio da transposição didática (TD), já que ela compreende subsídios teóricos e, mais do que isso, questões práticas de como lidar com os diferentes aspectos inerentes ao processo de ensinoaprendizagem da LM. A ANL/TBS contribuiria, ainda, com conceitos teóricos viabilizadores de uma concepção discursivo-argumentativa da língua.

No decorrer do capítulo, a autora traça um panorama histórico da TD, apropriando-se para tanto dos estudos de diferentes teóricos para, em seguida, entrar na questão da sequência didática, conceito importante para o êxito da TD e, consequentemente, para o êxito da aprendizagem da língua.

Ainda neste capítulo, considera o papel da TD no ensino da LM, através da análise do saber a respeito da oração relativa a partir dos manuais de LP, tanto do ensino fundamental quanto do médio. Para Alcançar o objetivo, ela analisa quatro livros didáticos indicados pelo MEC (PNLD), sendo dois de EF ( $8^{\mathrm{a}}$ série) e dois do EM (3 série).

Essa análise configura-se em material importante, pois foram escolhidos manuais didáticos bem conhecidos, o que desperta e motiva o 


\section{4}

interesse do professor em rever tais apresentações e consequentemente reavaliar sua prática de ensino.

Já no capítulo quatro, a autora conceitua a ANL (Teoria da Argumentação na Língua), apresentando todo o processo evolutivo da teoria até sua versão atual, a TBS (Teoria dos Blocos Semânticos). Devese acrescentar que talvez seja este o capítulo de leitura mais difícil para os professores que atuam na educação básica, visto que essa teoria ainda não é muito difundida nos cursos de atualização oferecidos à grande maioria dos professores e até mesmo para alguns acadêmicos dos cursos de letras.

Após desenvolver o conceito de argumentação na língua, o capítulo apresenta detalhadamente a TBS, o que implica em discutir a argumentação interna e a argumentação externa, conceitos esses que serão de suma importância para a análise semântico-enunciativa do funcionamento argumentativo da oração relativa, que será produzida a partir de duas crônicas publicadas no jornal Zero Hora (Porto Alegre, $\mathrm{RS})$.

O capítulo cinco traz uma análise consistente dessas crônicas, no que diz respeito ao funcionamento linguístico das orações relativas empregadas na língua cotidiana e a possíveis regularidades nesse uso.

Para desenvolver essa análise, é posta em prática a transposição didática, não sem antes detalhar passo a passo essa metodologia e fazer recortes textuais adequados à análise das orações relativas. A partir da teorização da TBS, a autora busca o papel argumentativo da oração relativa no enunciado, através de exemplos e explicações com base teórica e com exemplos práticos, a partir das crônicas selecionadas

O capítulo cinco é encerrado com a sistematização dos dados levantados, a partir da análise semântico-argumentativa do funcionamento discursivo das orações relativas. Tendo presentes essas constatações, Wittke retoma a análise dos livros didáticos apresentada no capítulo três e tece comparações entre os textos dos dois suportes textuais (livro didático e jornal), no que diz respeito às orações relativas.

Esse capítulo merece destaque em termos de importância para o professor de LM porque apresenta, de forma muito prática, questões metodológicas que podem ser remodeladas a partir do texto escolhido no momento que antecede à TD, tornando-se, assim, mais uma 
ferramenta de trabalho na busca da implementação das propostas dos PCNs.

Por outro lado, o uso constante de siglas pouco usuais no universo de saberes do professor de LM pode tornar a leitura complexa e causar certo desconforto em relação à teoria apresentada.

$\mathrm{Na}$ conclusão do estudo, Wittke retoma questões já abordadas no trabalho para dar-lhes uma sustentação prática e teórica, como a importância de o trabalho linguístico ser revisto, no sentido de abandonar os velhos e tradicionais exercícios gramaticais que não levam em consideração o uso da língua, a qual deve ser entendida e estudada como materialidade linguística impregnada de sentido.

Através da análise semântico-argumentativa da oração relativa, a autora mostra que é possível colocar em prática o ensino discursivo de $\mathrm{LM}$, defendido pelos PCNs, assim como reforça a tese de que é o fato de construir sentido, de saber argumentar, que deve prevalecer no estudo dos conteúdos linguísticos.

Cabe salientar que o fato de a abordagem recair em apenas um dos tantos saberes linguísticos (a oração relativa) de forma alguma invalida o trabalho no sentido de suporte teórico para o professor de LM, pois proporciona uma abertura para que todos os elementos linguísticos sejam pensados sob a ótica da análise semânticoargumentativa, trazendo um novo fôlego para o ensino de LM na educação básica, sem, com isso, abandonar o ensino da gramática, aqui vista como uma prática enunciativa capaz de produzir significado, tanto para quem ensina quanto para quem aprende.

Recebido em 19/01/09. Aprovado em 12/02/09. 